\begin{tabular}{|c|c|}
\hline rist & Malaysian Journal of Social Sciences and Humanities (MJSSH) \\
\hline Malaysian Journal of & Volume 6, Issue 8, August 2021 \\
\hline (MJ-SSH) & e-ISSN : 2504-8562 \\
\hline & $\begin{array}{l}\text { Journal home page: } \\
\text { www.msocialsciences.com }\end{array}$ \\
\hline
\end{tabular}

\title{
Analyzing The Influence of Job Description and Personality Towards Business Performance: A Case Study of RonaRias
}

\author{
Salma Rafif Robi1, Aria Bayu Pangestu ${ }^{1}$ \\ ${ }^{1}$ School of Business and Management, Institut Teknologi Bandung, Indonesia \\ Correspondence: Salma Rafif Robi (salma_rafif@sbm-itb.ac.id)
}

\begin{abstract}
Human Resource Management exists in a company or organization because of employees or people who work together to achieve the company's vision. Human Resource Management can help to see the performance of employees and all their achievements in the company. A group of people in a company or organization is called a team. Start-ups are new startup companies that are still leading to product development and market research. A startup team refers to a group of people with a specific idea that leads to executing a business. So, usually, a team that aims to build a start-up starts execution with limited human resources. The existence of these limitations requires the team at the start-up to analyze the part of the work that needs to be filled with people who are suitable for their positions. So it is essential to do a job analysis and job description for each role or position. Roles at work can be carried out with the competencies possessed by team members; for that reason, it is important to be aware of one's abilities and the work interests they have. Furthermore, a person's personality shows how a person's work style or decisions on every problem. Myers and Briggs's theory divides personality types into 16 out of four large-scale psychologist types: extrovert/introvert, observant/intuitive, feeling/thinking, assessing/looking for prospects. So, Human Resource Management has become necessary for all categories of companies, newly established and successful ones, to control and improve their employees to make a better company. RonaRias is a start-up company engaged in the beauty industry that provides make-up and model services for weddings, engagements, and product photos. Established in January 2021, but the development of income is continually declining. It is necessary to identify the problem, find the cause to be resolved and become a business that continues to show growth. The problem is that there are limited abilities and positions that people in their respective fields do not fill. Therefore, the researcher decided to analyze the abilities that the team members were aware of and conduct an assessment of their personality types. The RonaRias team's personality type assessment was carried out by filling out the online NERIS Type Explorer® Scale. Knowing the team personality type from RonaRias helps researchers understand the background of team members' work styles and why they have these competencies. As is the case for marketing, his intuitive nature encourages him to continue to think creatively because he is an INFP-T. This research was conducted with a qualitative approach. Conduct semi-structural interview sessions and focus group discussions with variable indicators related to job interest, business building, and job loyalty. The data obtained from the interviews and focus group discussions was processed using open coding to determine the negative and positive tendencies of the respondents' answers. After the analysis, the researcher saw that the competence of the respondents and their work styles were related to the type of personality they had. So, as a start-up founder, it is vital to know each other's personalities to allocate work according to their interests and take care of each other according to their respective personalities. The researcher also recommends that start-up founders pay attention to aspects of human resource management because employees are essential to achieving company goals. So it needs to be done by people who are following their fields.
\end{abstract}


Keywords: human resource management, start-up, competencies, personality types, job position

\section{Introduction}

RonaRias is a business focusing on beauty services, they provide makeup, and model services on one platform based in Bandung. They are concerned about user convenience, thus RonaRias aim to provide the services website-based that can filter the services with female's needs. With the value of connecting beauties without any insecurities, they believe that RonaRias could give the access to ease the beauty service needs, and empower the beauty-preneurs. Now RonaRias already have 16 makeup artists and 8 models that are ready to give the best service of beauty.

As a result of the team management and job description not being distributed effectively, each member performed business activities in parallel, not based on the division job description. This affects job effectiveness and business performance, especially when progress is slow. This issue arose due to multiple people completing one or more jobs in the company. Creating and managing the job description becomes the root cause, and it is essential to distribute the job in line with personal competence to perform well and increase business performance. Having a right job description is crucial in a company, start-up, or organization because a flawed job analysis method leads to low work satisfaction, employee rotation, and efficiency (Wolonciej, 2018).

\section{Literature Review}

\section{Human Resources Management on Startup}

Changing employee competencies and motivation levels (BARTEL, 1994) can result in faster and better business process implementation (Koch and Mcgrath, 1996), which applies to various organizational terms. According to Binks and Ennew (1996), small businesses must consider human resource strategies. The threat of not having enough human resources to grow explains why many small businesses choose not to grow. Thus, implementing HRMS in new businesses can be a critical stage in their development (Davila and Foster, 2007).

\section{The Importance of Job Description in Start-up}

A lean start-up requires new procedures that are distinct from previous routines, according to previous research (Edison et al., 2015). However, clear job descriptions help maintain productivity, which impacts firm performance (Sels et al., 2006). Individual and group motivation, participation, operational excellence, and organizational citizenship are valued in the high performance period, according to Bendickson et al. (2017). (Thoman and Lloyd, 2018).

A clear job description was important, but start-ups have a different culture and organizational system, so it had to be modified. Staffing, self-management teams, decentralized decision-making, training, flexible work assignments, communication, and compensation are all typical emphases in Human Resource Management (HRM) practices (Evans and Davis, 2005) which benefit The extent of this procedure varies depending on the job and the organization. The best candidate for the job is chosen based on knowledge, skills, and abilities (Bendickson et al., 2017). Employees are empowered when working in self-managed teams, and they can show initiative and personal growth while innovating (Heimovics et al., 1993). 


\section{Business Performance}

Business performance measures how well new businesses can meet their growth targets (Amedofu et al., 2019). Performance terms are also commonly used in organizations with human resources that support the organization's goals. According to Neely (2007), performance measurement is a broad topic. Accounting, operations management, marketing, finance, economics, psychology, and sociology all have active researchers. Performance can be differentiated at hierarchical levels, with one level's outcome influencing performance at the next (Sels et al., 2006).

\section{Accounting Perspective}

Accounting success metrics have frequently been the cornerstone of quantitative approaches to measuring performance (Neely, 2007). Therefore, high-performance managers are in charge of generating sales revenue and managing production or service delivery costs (Thoman and Lloyd, 2018). (Neely, 2007). So profit is a good performance metric.

\section{Marketing Perspective}

Managers should measure not only financial performance but also non-financial performance, according to Neely (2017). However, measuring marketing performance appears to be more difficult due to unpredictable external factors like customers and competitors. That does not mean marketing perspectives cannot help measure performance, leverage previous jobs, or improve manufacturing productivity. Thus, efforts to measure output per input unit are usually used to assess marketing contributions to business and industry success (Neely, 2017). For Sullivan and Abela (2007), marketing performance measurement research aims to assess the impact of marketing activities on intermediate outcomes (customer thoughts, feelings, knowledge, and behavior) on the company's financial performance.

\section{Customer Service}

Consumers have expectations for the products and services they buy, and their satisfaction varies depending on how well the consumption experience meets or exceeds those expectations (Neely, 2017). Customer satisfaction is perhaps the most recent business performance metric to gain widespread attention (Neely, 2017). (Kaplan and Norton, 1996).

\section{Loyalty}

Unlike previous discussions, where customer satisfaction is defined as meeting user expectations for a product, Neely (2017) found that customer satisfaction is determined by whether buyers continue to buy from the business. To achieve this, the marketing department must create a customer loyalty program that encourages frequent and exclusive purchases (Barton, 1999).

\section{Brand Equity}

Brand value is the total value of a brand as a separable asset. Brand strength is a measure of consumer attachment to a brand (Feldwick, 1996). The 'brand equity yield' refers to the brand's strength at a given time as a result of these assets in a particular market and competitive environment (Kapferer, 2008). Because brand equity is an essential measurement for years and significant marketing expenditures, Feldwick (1996) states that separating brand assets, strength, and value could help resolve domain confusion about brand equity (Neely, 2017).

Although marketing is non-financial, it influences marketing performance measurement and overall firm performance (Sullivan and Abela, 2007). Also, Neely (2017) stated in his research that non-financial metrics are especially beneficial as a foundation for establishing reliable baseline data, which typically takes a year. Try to link non-financial indicators to future financial results. 


\section{Operational Perspective}

The performance of an organization or business can be measured by analyzing the state of its various divisions, such as finance, marketing, and operations. Neely (2017) explained the past, present, and future business performance of operations. Operational efficiency was the focus of operations before 1980. The Japanese economy's success also demonstrates a well-designed operational system (Hayes and Abernathy, 2007). Between the 1980s and 2000, operations managers were also curious about how well their operations were performing, as the strategic role of operations in organizations was increasingly recognized (Neely, 2017). According to Neely (2017), the new economy proliferated in 2000 and beyond. To ensure that autonomous operations continue to provide excellent customer service, managers need information on inter-and intra-organizational performance. From manufacturing to customer service, and operational perspective can improve a company's customer experience.

\section{The Impact of Job Description on Business Performance}

A good job description and quality supervision can be key motivating forces for employees in a business, even when resources are limited (Patoko and Yazdanifard, 2014). Depending on the organization's other practices, HRM systems may improve or deteriorate performance (Wilkinson et al., 2019). Workplace motivation is a key factor in a company's success. A job is a well-structured organizational unit, according to Pato's 2017 research. Before creating a job, it is necessary to conduct a job analysis.

\section{Competencies in Human Resources and Management}

Competency is the ability to perform a specific task or deliver a measurable outcome (Succar et al., 2013). Professional competence, or being sufficiently capable and allowed to perform certain tasks, has long been a goal (Mulder et al., 2007). For example, the analysis can be used to generate competency frameworks in the recruitment process or HRM to ensure the right person is hired. Succar et al. (2013) define competency as knowledge, skill, and personal traits. Directly influencing and classifying personal skills are the components of competence. Determining individual performance in three distinct competency manifestations is believed to be used to describe, assess, and predict individual performance. Thus, functional analysis or a variant can define technical competencies.

\section{Personality Traits}

Personality is a vague term used to describe behavioral consistency and individuality (MAKWANA and B DAVE, 2020). Personal reactions, attitudes, personality styles, and/or motivational traits were assessed in addition to intellectual abilities such as brainpower or accomplishment (MAKWANA and B DAVE, 2020). The Myers-Briggs Type Indicator consists of four basic mental processes (sensing, intuition, thinking, and feeling) and two attitudes toward the world around us (extraverted or introverted) (Mccaulley and Martin, 1995).

\section{Methodology}

The researcher used an in-depth semi-structured interview, Personality Assessment - NERIS Type Explorer ${ }^{\circledR}$ Scale, and Focus Group Discussion to collect data. The in-depth interview and focus group are being conducted to elicit more specific and insightful responses from the participants. Furthermore, an in-depth interview is an excellent way to learn more about the participants' experiences, perspectives on the RonaRias business, and the ability to precisely understand the right position for them. The online personality assessment helps the researcher in understanding the respondents' personality traits to correlate the respondents' daily basis through their work circumstances. This aided the researcher in figuring out which factor influences the respondent's job performance. 
Figure 1: Research Design

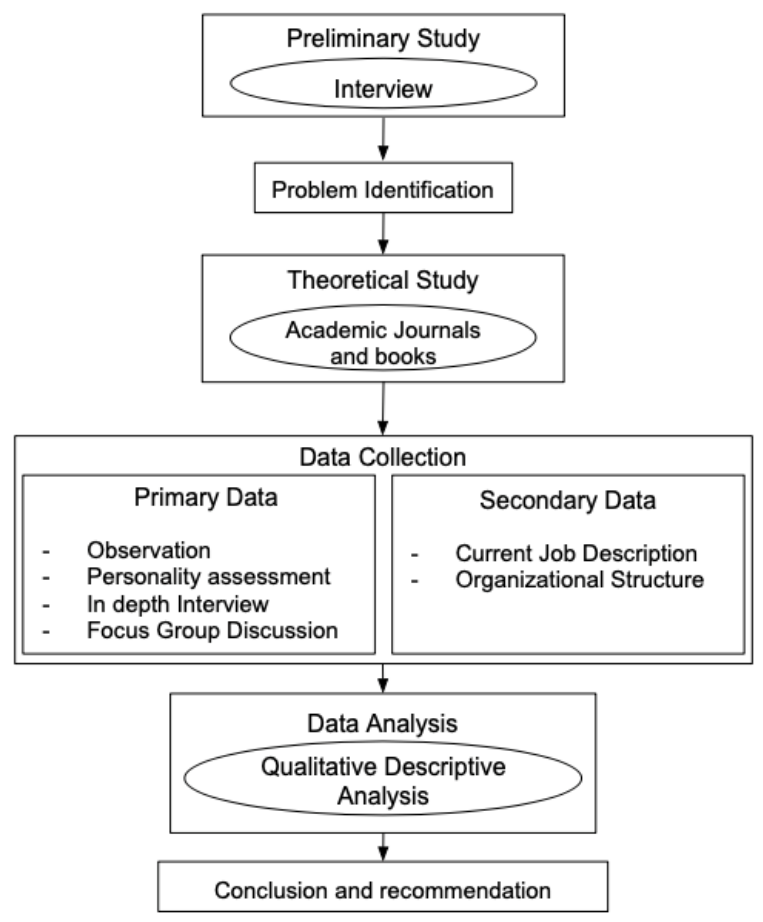

\section{Analysis and Result}

\section{Observation}

This observation helps the author understand the situation at RonaRias at the time. The author, a member of the RonaRias team, identified the business process and each member's internal communication during the analysis period from January to May 2021. Several issues hampered RonaRias' business growth during the author's six-month observation. However, just because the team agreed to create an idea for a problem that has been confirmed does not guarantee the business will grow. The decline in business performance from January to May 2021 is evidenced by declining revenue and several unmet KPIs. Aside from external conditions (pandemic), internal human resources are still lacking. According to the author, several current jobs positions carried out by the RonaRias team do not have an excellent ability to control that section. Thus, business performance is hampered by requiring two people to manage certain tasks. It slowed down the business. However, the RonaRias team cannot meet the KPIs.

\section{Personality Test Using the Myers-Briggs Type Indicator}

Members' personalities as figured out by NERIS Type Explorer® and Myers-Briggs's theories. Knowing the member's Personality Type helps the researcher evaluate their performance and strategies for the new job construction fits their interest and personality (Järlström, 2000).

i. Respondent 1 as Chief Financial Officer, ESFJ-T, Extraverted, Observant, Feeling, and Judging personality traits. Extrovert $68 \%$ Observant $61 \%$ Sensing $76 \%$ Judging $55 \%$

ii. Respondent 2 as Chief Operating Officer, ESFJ-T, Extraverted, Observant, Feeling, and Judging Personality Type. Extrovert 71\% Observant 66\% Sensing 72\% Judging 64\%

iii. Respondent 3 as Chief Marketing Officer, INFP-T, with Introverted, Intuitive, Feeling, and Prospecting personality traits. Introvert 71\% Intuitive 76\% Feeling 74\% Prospecting 51\%

iv. Respondent 4 as Chief Executive Officer, ENFJ-T with Extraverted, Intuitive, Feeling, and Judging personality traits. Extrovert $69 \%$ Intuitive $54 \%$ Feeling $76 \%$ Judging $62 \%$ 


\section{Interview}

Due to the current limitations of pandemic COVID-19, the researcher conducted online interviews with RonaRias team members via Google Meet. Despite this limitation, the researcher cannot see the interviewee's gestures, eye contact, or even emotions. As a result, the researcher focused on words related to the interviewees' jobs. During this interview stage, the researcher seeks data from two major areas: the interviewee's experience and perception of their current job position at RonaRias, and their job interest.

Table 1 - Interview Coding Result

\begin{tabular}{|c|c|c|c|}
\hline $\begin{array}{l}\text { Related } \\
\text { Variable }\end{array}$ & Positive & Negative & Substantial \\
\hline SEI & 14 & 9 & $\begin{array}{l}\text { Match with her job interest in Marketing; Enjoy this position and } \\
\text { love economics; Can discover new things; Handle ideation to } \\
\text { execution strategies; No skill and dizzy; No experience and ability; } \\
\text { Repetitive work; No skill and tired; Willing to explore many things; } \\
\text { Only have the basic knowledge and competition experience; Have } \\
\text { creative thinking skill }\end{array}$ \\
\hline JSE & 3 & 11 & $\begin{array}{l}\text { Still in early-stage start-up; Perfectionist; Do not understand the job } \\
\text { scope; Report that does not match the list of clients; Have to make a } \\
\text { breakthrough; Have to learn and understand by herself, and it is } \\
\text { hindering the business performance; Not yet capable of; Be } \\
\text { responsible; In-depth understanding of the operation process }\end{array}$ \\
\hline $\mathrm{BC}$ & 19 & 1 & $\begin{array}{l}\text { Ideation exploration; Initiate ideation for products and customer } \\
\text { relationship for increasing sales; Love to talk to someone, even a } \\
\text { stranger; Able to convince someone for a particular idea; Likes to } \\
\text { be in an organization; Strategize ideation to improve the business; } \\
\text { Challenging and have previous experiences in; RonaRias's } \\
\text { operation; Internship experience in Marketing; Keep exploring; } \\
\text { Want to keep trying; Have several ideations for improving the } \\
\text { business and have family business; Try to learn Photoshop; } \\
\text { Depressing }\end{array}$ \\
\hline MIH & 9 & 1 & $\begin{array}{l}\text { Innovations are not liked by others; Keep try to search for the } \\
\text { declined reason; Create discount campaign, testimonial. etc; } \\
\text { Understand the market for improving the business; Join free } \\
\text { workshop as an improvement opportunity }\end{array}$ \\
\hline RWH & 3 & 1 & $\begin{array}{l}\text { Creative thinking skill ability; Enjoy the job and have the ability; } \\
\text { The business has uncertain conditions for every activity we want to } \\
\text { execute; Complicated }\end{array}$ \\
\hline BTB & 7 & 2 & $\begin{array}{l}\text { Lower work motivation; Understand current market needs; Looking } \\
\text { for an insight; For her own business; Take some time can keep back } \\
\text { to work; Self-improvement for good performance }\end{array}$ \\
\hline LTV & 4 & 3 & $\begin{array}{l}\text { Want to do more than instructed; Freely company for an employee's } \\
\text { creativity; There is no instruction; A strict company and haven't } \\
\text { same value as herself; Feel tired to do more }\end{array}$ \\
\hline
\end{tabular}

Interviewing data helps the researcher distinguish between respondents who work in RonaRias that match their interests and competencies. The respondents lack work that matches their interests or even their skills. Each member's job interests and competencies affect the RonaRias business performance. The Building Capability variable interprets that Respondent 3 has been realizing her job interest, which is still related to her role in RonaRias and Respondent 12 for their future career. A negative response from Respondent 2 explains her lack of interest in a position related to calculations (ex: finance). According to the Self-Evaluated, 14 positive responses represent the respondents' perception of each role 
in RonaRias, whether a match exists or not. Respondents 2 and 3 both gave nine negative responses. Respondent 2 explains why she dislikes her current role as $\mathrm{COO}$ at RonaRias, and Respondent 3 explains why she dislikes her job description as marketing at RonaRias despite her job interest. Also, Job Site Experience is in the top three, with 11 negative responses from respondents who explain their obstacles while working in RonaRias. Respondents 1 and 2 are most often in a position that does not align with their interests. They also give three positive responses about enjoying their current role in RonaRias. The RonaRias team members understood their sensitivity and reaction to their interest through their competencies while in RonaRias and for the future after RonaRias.

\section{Focus Group Discussion}

As a result of the FGD session and interviewees' responses, the researcher concluded that the main reason for RonaRias' slow business performance is a lack of ability and competency. The researcher asked an added question about the importance of allocating jobs based on personal interests and skills. Also, she said she wanted to work in business development, which matched her interest. However, when asked to choose her division, Respondent 1 is perplexed. She wants to stay in finance because she enjoys it. Her economics education also gave her the confidence to keep choosing finance.

However, the researcher concludes that it is essential to have responsibility based on interests and competencies that influenced business performance. One of the interviewees, Respondent 1, had a different perspective on the topic of entrepreneur flexibility. She believed that she could understand the entire business as an entrepreneur, not just marketing, finance, and operations. A leader must know everything. Thus, in Entrepreneurship SBM ITB, there is no division into concentrates. Respondent 2 agreed because business was dynamic. However, the researcher believes the $\mathrm{C}$-level must have specific ability, such as a Chief Marketing Officer with marketing ability. Moreover, Respondent 3 must comprehend the general business conditions if the $\mathrm{C}$ level is also the founder, as this may affect the responsibility scope. So, they can keep an eye on it.

\section{Discussion}

The researcher correlated data observation, personality test results, data interview, and FGD results to identify the research problem. The researcher concluded that Human Resources lacked management. It was shown by unmet KPIs, delayed aims, and people with disabilities handling some goals. A Consul (ESFJ) is a person who enjoys any role if they can contribute meaningfully. Even though they are not in their job interests (Respondent 2 is interested in Business Development but has basic accounting knowledge and competition experience), they keep trying to work well within their constraints. The Chief Marketing Officer (Respondent 3) has the perfect job for her personality. She is an INFP Mediator who enjoys fantasy. Furthermore, the Chief Operating Officer (Respondent 4) wants to lead the RonaRias, based on her Protagonist personality test results. Regardless, the four C-level positions are divided into two people who fit the job interests and two who do not, affecting and visible in RonaRias' business performance.

The researcher got some perceptions from the interviewees from their positive and negative responses related to seven variables to identify job interests and responsibilities that affected business performance. Begin with the Self-Evaluated variable to show the researcher's assumption of Respondent 1 is incorrect. She is in finance at RonaRias because she has basic accounting knowledge from high school and enjoys it. Respondent 2 assures she did not want to be in the operation because she lacked experience and ability, but her statement was more pessimistic. However, she is intrigued by the prospect of learning new skills and expanding her knowledge of running a tech company from concept to execution. She also likes to create content plans, which relates to her creative thinking skills. Because RonaRias is still a young company, she gets tired of thinking and planning content to increase brand awareness. Respondent 3 is an intuitive person who is constantly exploring new ideas. Even though she knew she wanted to work in marketing, she still looked into it. Because the marketing scope has widened, she keeps trying out different marketing aspects like content planning, design, and analysis to see which she prefers. 
During the RonaRias, both those who fit their job interests and those who did not encounter several obstacles related to Job Site Experience. However, Respondent 2's regret of her obstacles while working at RonaRias influenced the data, presenting a higher negative response. Her lack of knowledge and experience forced her to learn independently, which slowed down RonaRias' business process and made her feel overwhelmed. Nevertheless, she tried to use her network knowledge to grasp the operation process better. Reflecting on the FGD results, the researcher identified several moments when Respondent 2 felt confused and questioned her work. As shown by Respondent 2's personality test results, she has a Turbulent Consul Personality Type, which means she values her duties and responsibilities above all else. So, she must keep up the excellent work as an operation. The Turbulent personality type was also observant. She is often a stabilizing force that carries out tasks. Their approach is "hands-on," as they work on real-time projects.

Respondent 2 in the Building Capability variable wants to work in business development and marketing. Because she has previous experience in RonaRias' operations, she is more likely to choose Business Development. Another reason was the work process similarity between operations and business development. Her extraverted traits and communication skills fueled her job interest. She chose business development because she enjoys challenges and learning new things. Make It Happen by Respondent 2 tries to strengthen her business development ability by joining free workshops to improve her workability. So, it helped her prepare for work. She was not interested in other positions such as finance because she had no interest, and it was depressing for her. In the FGD session, she also states that working in her field of interest helps her feel more connected and responsible. She would gain more responsibility as a judge if she worked in business development because she can be responsible for an unsuitable job. She will be more responsible and perform better at work if her position is correct.

On the other hand, the researcher examined Respondent 1's Job Site Experience statement of her financial obstacles. Like Respondent 1, the researcher has not met any significant issues in her work. Miscommunication between teams affects the client's match list, which impedes the recording process. Nevertheless, Respondent 1 handles overcoming obstacles by reporting every financial detail, income, and result. Like Respondent 2, the researcher can see that Respondent 1 understands accounting and her personality traits as a judging person who has a strong work ethic to handle the tasks. So, she can be used in RonaRias' work and as finance.

Respondent 1 FGD believes that even though she was not interested in finance, the repetition of the job drove her to get used to it. Also, her FGD statement to the Related Work Habit variable will be the same whether she works faster or not because she keeps her responsibility. The Building Capability variable in the interview results also shows her interest in business development. The researcher explains her interest in generating ideas, pitching for a specific moment, and communication skills. Concerning the Make It Happens variable, the respondent acknowledges that implementing ideas may be difficult because others may not like them. Nevertheless, she will defend the idea by examining the rejected reason. This reflects her personality as an Observant who values logical thinking and the possibility of new ideas. And the FGD session. Respondent 1 is likely to choose finance if the RonaRias continues, while Respondent 2 is likely to choose marketing. However, she is more assured in finance due to her knowledge and previous schooling.

Despite the discussion of Job Site Experience and another variable, the researcher identifies Respondent 3 's obstacle as marketing. She has struggled to raise brand awareness for RonaRias because the company is still in its infancy, and no breakthrough innovation has yet occurred. Nevertheless, she keeps strategizing by launching a campaign to promote the variable Make It Happen. If no ideas come, she decides to brainstorm with the team to find new ideas. Respondent 3 works in marketing because she is not under pressure. The SEO of analyzing the data is quite complicated, and she will have to recognize her discomfort in marketing. Those are linked to Related Work Habit. Respondent 3 stated in the FGD that working in her field of interest drives her to explore and learn quickly. Her previous experience as Human Resources at the organization did not suit her interests, so she quit because she was uncomfortable in the position. She could easily quit and pursue something else if she were unhappy with something in her life. 
The researcher then analyzes Respondent's perception while in RonaRias and how it relates to their personality. From the interview and FGD results, their willingness to build business and job loyalty of RonaRias team members. To date, all team members have responded to each job description. However, there are times when business progress seems slow, affecting RonaRias' revenue.

First, the researcher looks at the interviewees' perception of their responsibility to keep performing to support the business. Starting with Respondent 1, she intends to resign if the issue is a lack of work motivation or an unsuitable workplace. However, if it is her own business, she will do more because she has invested time and energy into it, and she wants it to succeed. In addition, she has helped in the development of her family's business. For her own business, she tends to follow her heart and emotions as a Feeling trait individual. Then, when demotivated, Respondent 2 tends to brainstorm with other team members to help her develop new ideas. So, it refreshes her mind to continue her marketing work. A perspective individual, she initiated brainstorming with the team. She is constantly brainstorming to increase her creativity and productivity. Respondent 3 will also take some time to re-energize before returning to work; she will also seek feedback from her colleagues to understand where she can improve her performance. Her work motivation strategies reflect her personality traits as a Judge, who has a planning strategy by collecting feedback and improving her performance. Temperate Consuls with Judging traits prefer structure and planning over impulsiveness.

A second barrier to RonaRias's business growth is the researcher's focus on questions related to RonaRias's founder role and responsibility as an SBM ITB college student, according to Respondent 1. So, it hampered the performance. However, according to Respondent 3, RonaRias' team can take a long time to rest after completing their coursework, thus forgetting about the responsibility of continuing the business. She feared making mistakes in some business activities. Will it be wrong, or right? Respondent 2 believes her lack of knowledge in the beauty field contributed to her irresponsibility and poor performance. However, more work is needed to strengthen and expand the company.

Respondents 1 and 2 are more likely to contribute more to their own business, while Respondent 3 does more than she is instructed to do while working in a company. The FGD session also revealed that the right position, experience, knowledge, consistency, and freedom to run a business without any boundaries from college tasks would be driven to be faster to handle the business problem. It can be seen from the related data collected by the researcher from the personality assessment test, interview, and FGD results, even though each respondent had a differing opinion. However, it is not solely due to their personality that has hampered RonaRias' business performance. Nevertheless, their job duties required them to be responsible and consistent. Every problem and response from the RonaRias team was influenced by their traits, which researchers had not recognized. Moreover, an early-stage start-human up's resources affect the business and the way they work. So essential issues arise.

The researcher can suggest that the job description and allocation may be adequate to improve the business performance of RonaRias that matches personal interests and competencies. In contrast, people who work in positions they enjoy will be more motivated to improve their skills and consistency. Then their personality stands for how they will work with their soft skill. People like Respondent 2, who are interested in business development, stay put. The technical aspects will be separated. RonaRias must hire other Chief Technology Officers to handle the technician process. Thus, RonaRias team members can focus on each division to increase the business performance.

\section{Conclusion}

To find out why RonaRias' business performance was delaying, this research was carried out. However, the researcher hopes to improve RonaRias' human resource quality through this study. To begin with, the researcher assumes that the team members affected the company's performance and that the right person did not run some divisions. Nevertheless, the researcher conducted a preliminary study to identify the issue. The researcher discovered a link between job interest, team member competencies, personal performance, and business performance, as revealed by the RonaRias team's personality assessment 
results. RonaRias current business conditions and KPIs shape the researcher to analyze the human resource relationship.

The researcher concluded from the data collection and analysis that the ongoing RonaRias reflected each member's personality traits. Each personality's likes and dislikes are marked. For example, in marketing, the person stated that she likes creative ideas because a Mediator thinks creatively, which leads to productivity. However, his personality influences her choice of job position. Furthermore, external factors influence their behavior in dealing with situations, such as the fact that the RonaRias project is carried out alongside the team members' responsibilities as college students. So it affected the team's confusion and feelings to strategize ideation.

\section{Research Implication}

The researcher advises RonaRias to reallocate job positions for each member based on their recognized competencies and interests. While doing work based on interests, it is easy to improve work quality and consistency. Moreover, their personalities can reveal their job support strategies. People interested in their work will be more flexible and motivated to improve their work performance, despite their lack of knowledge. Thus, the business will grow as long as human resources grow.

Understanding the company's resource needs is critical for founders, especially CEOs. It is essential to recognize the type of team to build and recruit people based on their needs. Founders must be able to recognize each other's personalities. However, despite the limitations, mutual support is needed to achieve business goals through business performance.

\section{References}

Amedofu, M., Asamoah, D., Agyei-Owusu, B., 2019. Effect of supply chain management practices on customer development and start-up performance. Benchmarking 26, 2267-2285. https://doi.org/10.1108/BIJ-08-2018-0230

BARTEL, A.P., 1994. Productivity Gains from the Implementation of Employee Training Programs. Ind. Relations A J. Econ. Soc. 33, 411-425. https://doi.org/10.1111/j.1468-232X.1994.tb00349.x

Barton, T.L., 1999. Measuring Customer Satisfaction: Survey Design, Use, and Statistical Analysis Method, Quality Management Journal. https://doi.org/10.1080/10686967.1999.11919216

Bendickson, J., Ligouri, E., Midgett, C., 2017. High Performance Work Syetems: A Necessity For Startups. J. Small Bus. Strateg. 27.

Binks, M.R., Ennew, C.T., 1996. Growing firms and the credit constraint. Small Bus. Econ. 8, 17-25. https://doi.org/10.1007/BF00391972

Davila, A., Foster, G., 2007. Ok Parece repetitivo Management Control SystemsEarly-Stage Startup Companies. Account. Rev. 82, 907-937.

Edison, H., Wang, X., Abrahamsson, P., 2015. Lean startup: Why large software companies should care. ACM Int. Conf. Proceeding Ser. 25-29-May-. https://doi.org/10.1145/2764979.2764981

Evans, W.R., Davis, W.D., 2005. High-performance work systems and organizational performance: The mediating role of internal social structure. J. Manage. 31, 758-775. https://doi.org/10.1177/0149206305279370

Feldwick, P., 1996. What is brand equity anyway, and how do you measure it? Int. J. Mark. Res. 38, 85-104. https://doi.org/10.1177/147078539603800201

Kapferer, J., 2008. The New Strategic Brand Management: Creating and Sustaining Brand Equity Long Term Kogan Page Series New Strategic Brand Management: Creating and Sustaining Brand Equity Series, Igarss 2014.

Kaplan, R.S., Norton, D.P., 1992. The Balanced Scorecard - Measures that Drive Performance. Harvard Bus. 71-79.

Koch, M., Mcgrath, R.G., 1996. I- Recource Management Policies Do Matter. Management 17, 335354. 
Hayes, R.H., Abernathy, W.J., 2007. Managing our way to economic decline. Harv. Bus. Rev. 85.

Heimovics, R.D., Herman, R.D., Coughlin, C.L.J., Hennan, D., 1993. Nonprofit in Depedence Analysis Organizions : of. Public Adm. Rev. 53, 419-427.

Järlström, M., 2000. Personality preferences and career expectations of Finnish business students. Career Dev. Int. 5, 144-154. https://doi.org/10.1108/13620430010371919

MAKWANA, K., B DAVE, G., 2020. Confirmatory Factor Analysis of Neris Type Explorer ${ }^{\circledR}$ Scale a Tool for Personality Assessment. Int. J. Manag. 11. https://doi.org/10.34218/ijm.11.9.2020.025

Mccaulley, M.H., Martin, C.R., 1995. Career Assessment and the Myers-Briggs Type Indicator. J. Career Assess. 3, 219-239. https://doi.org/10.1177/106907279500300208

Mulder, M., Weigel, T., Collins, K., 2007. The concept of competence in the development of vocational education and training in selected EU member states: A critical analysis. J. Vocat. Educ. Train. 59, 67-88. https://doi.org/10.1080/13636820601145630

Neely, A., 2007. Business Performance Measurement: Unifying Theories and Integrating Practice, Second Edition, Cambridge University Press, Cambridge. https://doi.org/10.1017/CBO9780511488481

Pató, B.S.G., 2017. Formal options for job descriptions: theory meets practice. J. Manag. Dev. 36, 1008-1028. https://doi.org/10.1108/JMD-01-2016-0019

Patoko, N., Yazdanifard, R., 2014. The Impact of Using Many Jargon Words, while Communicating with the Organization Employees. Am. J. Ind. Bus. Manag. 04, 567-572. https://doi.org/10.4236/ajibm.2014.410061

Sels, L., De Winne, S., Delmotte, J., Maes, J., Faems, D., Forrier, A., 2006. Linking HRM and small business performance: An examination of the impact of HRM intensity on the productivity and financial performance of small businesses. Small Bus. Econ. 26, 83-101. https://doi.org/10.1007/s11187-004-6488-6

Succar, B., Sher, W., Williams, A., 2013. An integrated approach to BIM competency assessment, acquisition and application. Autom. Constr. 35, 174-189. https://doi.org/10.1016/j.autcon.2013.05.016

Sullivan, D.O., Abela, A. V, 2007. Measurement Ability and Firm “ T. J. Mark. 71, 79-93.

Thoman, D., Lloyd, R., 2018. A Review of the Literature on Human Resource Development: Leveraging HR as Strategic Partner in the High Performance Organization. J. Int. Interdiscip. Bus. Res. 5, 147.

Wilkinson, A., Bacon, N., Snell, S., Lepak, D., 2019. Human Resource Management.

Wolonciej, M.T., 2018. Do jobs matter more than nations? Cultural constraints on organizational performance. J. Organ. Chang. Manag. 31, 494-511. https://doi.org/10.1108/JOCM-04-2017$\underline{0137}$ 